\title{
Environmental drivers and plant species diversity in the Catalan and Andorran Pyrenees
}

\author{
Josep M. Ninot, Albert Ferré, Oriol Grau, Xavier Font, \\ Aaron Pérez-Haase \& Empar Carrillo (*)
}

\begin{abstract}
Ninot, J.M., Ferré, A., Grau, O., Font, X., Pérez-Haase, A. \& Carrillo, E. Environmental drivers and plant species diversity in the Catalan and Andorran Pyrenees. Lazaroa 34: 89-105 (2013).

In this paper, we analyse the spatial distribution of plant diversity in the Pyrenean area of Catalonia and Andorra, in parallel to the distribution of landscape descriptors that have been proven to be related to species distribution. We used a wide range of synthetic parameters that refer to physiography (area, main outcrops), bioclimate (length of the growing season, rainfall, potential evapotranspiration), and landscape structure (habitats richness and diversity). Plant diversity was mainly assessed through the data gathered in the Biodiversity Data Bank of Catalonia, which consists of over 300,000 records of 2,335 species of vascular plants. Spatial variation in all the aspects covered here was analysed separately for eight sectors in the study area, and along the altitudinal gradient.

Among the abiotic factors, bioclimatic parameters stood out for their regular variation -increasing or decreasing-along the altitudinal gradient. Noticeable differences were found between sectors, and were related to their physiographic particularities or location within the Pyrenees. Along the altitudinal gradient we found consistent shifts in the distribution of functional, ecological and phytogeographic plant groups. As for species richness, all the Pyrenean sectors gave a roughly similar pattern in the altitudinal gradient, with the maximum values found at low-medium altitudes and a regular decreasing trend towards the summits, coinciding with a steep decrease in habitats richness. Differences between sectors in plant diversity mostly depended on the altitude span of each and of other mid-scale landscape singularities, and were more evident between axial Pyrenean and pre-Pyrenean sectors. However, these regional differences also respond to historical biogeography, which is the foundation for understanding the altitudinal distribution of plants through species migration, extinction, and diversification over major Quaternary climatic variation.
\end{abstract}

Keywords: Bioclimate, biogeography, elevation gradient, endemism, habitats, life forms, species richness, vascular flora.

Resumen: Ninot, J.M., Ferré, A., Grau, O., Font, X., Pérez-Haase, A. \& Carrillo, E. Factores ambientales y diversidad de especies de plantas vasculares en los Pirineos catalanes y andorranos. Lazaroa 34: 89-105 (2013).

En este trabajo se analiza la distribución espacial de la diversidad vegetal en la zona pirenaica de Cataluña y Andorra. Además, y en paralelo se ha estudiado la distribución de los descriptores de paisaje que están relacionados con la distribución de las especies. Hemos utilizado un amplio número de parámetros de síntesis que se refieren a la fisiografía (área, principales afloramientos), bioclima (longitud del período de crecimiento, precipitaciones, evapotranspiración potencial), y estructura del paisaje (riqueza y diversidad de hábitats). La diversidad de especies se evaluó principalmente a través de los datos recogidos en el Banco de Datos de Biodiversidad de Cataluña, que consta de más de 300.000 registros de 2.335 especies de plantas vasculares. La variación espacial en todos los aspectos tratados aquí se analizó por separado para ocho sectores en el área de estudio, a lo largo del gradiente altitudinal.

Entre los factores abióticos, los parámetros bioclimáticos se destacaron por su constante variación creciente o decreciente, a lo largo del gradiente altitudinal. No se encontraron diferencias notables entre los sectores, y se relacionan con sus particularidades fisiográficas o la ubicación en el macizo pirenaico. A lo largo del gradiente altitudinal encontramos cambios consistentes en la distribución de los grupos funcionales, ecológicos y fitogeográficos de especies. En cuanto a la riqueza todos los sectores pirenaicos mostraron un patrón más o menos similar en el gradiente altitudinal, con valores máximos en altitudes media-baja y una tendencia decreciente constante hacia las cumbres, coincidiendo con una fuerte disminución de la riqueza de hábitats. Las diferencias entre los sectores dependen en su mayoría de los límites en altitud de cada uno y de otras singularidades del paisaje a media escala, y fueron más evidentes entre el área axial pirenaica y los sectores pre-pirenaicos. Sin embargo, estas diferencias regionales también responden a la biogeografía histórica, que es la

\footnotetext{
* Biodiversity Research Institute \& Department of Plant Biology. University of Barcelona. Av. Diagonal 643. E-08028 Barcelona. Email: jninot@ub.edu.
} 
base para la comprensión de la distribución altitudinal de los vegetales a través de la migración de las especies, la extinción y la diversificación entre las principales variaciones climáticas del Cuaternario.

Palabras clave: Bioclima, biogeografía, gradiente altitudinal, endemismo, hábitat, formas vitales, riqueza de especies, flora vascular.

\section{INTRODUCTION}

Our understanding of the spatial distribution of species diversity as related to ecological and historical factors is an important milestone in biogeography. It provides a conceptual framework to uncover causal factors for biodiversity, and a basis for improving conservation tools and policies. In the case of vascular plants' geography, much insight has been gained through traditional floristic approaches and phytosociological descriptions at small geographical scale (MUCINA, 2010; AgulLó \& al., 2010; RodRíGUEZ-Guitián, 2010; GAVILÁN \& al., 2011; FERNÁNDEZ \& MoLERO, 2011; SARIKA, 2012; RodRíGUEZ-RoJO \& al., 2012). The Pyrenees, together with other Iberian mountain landscapes, is a well-known area within southwestern Europe in terms of phytogeography. This has led to general assessments of flora, vegetation, and cartography (e.g. BoLòs \& Vigo, 1984-2001, VILlaR \& al., 1997-2001, CARRERAS \& VENDRELL, 2012; FONT \& al., 2013; GóMEZ \& al., 2013), and specific analyses focussed on particular issues of plant diversity.

Plant species richness has been analysed at a medium spatial scale by considering the Pyrenean area split into regular cells according to the UTM grid (LOBO \& al., 2001; LÓPEZ \& FONT, 2006; PÉREZ \& FONT, 2012) and by taking altitudinal gradient as the main variation factor (GRAU \& al., $2011,2012)$. In this way, higher species richness has been related to general spatial descriptors, such as altitude span, maximum altitude, physiographic heterogeneity, and location within the Pyrenean range. Altitudinal gradient underlies some abiotic factors that may play a key role in plant diversity, such as bioclimatic constraints (including the thermal regime and the balance between precipitation and water demand). Other abiotic factors independent of altitude may influence diversity patterns, such as the substrate characteristics (limestone outcrops or soil development).
However, biodiversity patterns are dependent on the scale used for the analysis. Therefore, to correctly understand biogeographic patterns it is important to analyse patterns at varying scales, focuses, and methods (CRAWLEY \& HARRAL, 2001). For instance, important components of plant diversity respond to small-scale phenomena (spontaneous vegetation dynamics after small-scale disturbance events), others respond to larger-scaled conditions (such as regional continentality or altitude-based thermal regimes). Further, we must emphasize the role of historical biogeography in analysing the spatial distribution of biodiversity. At plant species level, most of the present floristic structure can be explained by considering the most recent Pleistocene thermal oscillations and the Holocene climate, which forced massive species migration, extinction, and diversification (COMES \& KADEREIT, 1998; ThOMPSON, 2005; BirKs, 2008; PÉreZ \& al., 2013; LóPEZ SÁEZ \& al., 2013). The distribution and characteristics of the Pyrenean endemics illustrate some of these floristic changes (NINOT \& al., in review). More recently, the man-induced expansion of vegetation units related to grazing and farming, and the on-going addition of alien species to the Pyrenean flora, give a new dimension to these changes.

Our main objective is to explore the spatial distribution of plant diversity in the Pyrenean area of Catalonia and Andorra, in parallel to the distribution of landscape descriptors that have been proven to be related to species richness and singularity. In doing so, we establish and use a wide group of synthetic descriptors that refer to physiography, bioclimatology, landscape structure, and plant diversity in the area considered, and are compiled from ample regional data sources and local monographs, which aid understanding of Pyrenean biodiversity. We use a rich data bank on species occurrence in the area and GIS cartography built on physiographic descriptors, climatic variables and land cover units to explore 
relationships between causal factors (climatic, physiographic, and land use) and variations in vascular plant species richness, endemics richness, and distribution of the flora into functional, ecological and phytogeographic groups. The analysis is based on two spatial variation factors: the altitudinal gradient, and the distinction of eight sectors or two main ranges within the study area.

\section{MATERIAL AND METHODS}

The paper deals with the Catalan and Andorran Pyrenees, on which a large amount of data on flora, plant communities, and habitats is stored and easily available in data banks. This part of the Pyrenees was limited to the south by the contour line of $400 \mathrm{~m}$ asl, and to the north and west by the French and Aragon boundaries, respectively. The range includes: i) south-facing valleys extending from the northern main axis to inner depressions and valley bottoms (the axial Iberian Pyrenees); ii) southern secondary ranges parallel to the main chain, progressively reaching lower altitudes to the south and interspersed by lower lands (the pre-Pyrenees); and iii) the Aran valley, oriented northwards to the Aquitanic plain and to Atlantic influence.

In this Pyrenean area up to six vegetation belts can be distinguished (according to NINOT \& al., 2007): basal (up to 600-800 m asl), submontane (to $1,100-1,300 \mathrm{~m}$ asl), montane (to $1,600-1,800$ $\mathrm{m}$ asl), subalpine (to 2,200-2,400 m asl), alpine (almost to the summits) and subnival (uppermost areas of peaks and crests of the axial Pyrenees). In the area considered here, the basal belt is only well represented in the southern ranges, or prePyrenees, and is mainly covered by Mediterranean vegetation units. The submontane and montane vegetation belts are clearly medio-European in the parts of the axial Pyrenees more influenced by the Atlantic climate. However, the submontane belt has a more Mediterranean character in other axial areas, and above all in the pre-Pyrenean ranges, where sub-Mediterranean flora and vegetation are very noticeable. The three higher belts (subalpine, alpine and subnival) are the high mountain zone, where the dominant flora and vegetation are of Alpine character. There, the subalpine belt is characterized by widespread conifer forests and related scrubs and grasslands, and gives way upwards to the alpine belt through the treeline ecotone.

In order to assess the internal diversity of this complex mountainous area at a smaller scale (i.e. around 500-2,000 $\mathrm{km}^{2}$ ), we split it into eight sectors according to its physiographic and geobotanic heterogeneity, and partly following previous proposals (BolÒs \& VIGO, 1984; RIVAs-MARTíNEZ \& al., 1991). Since most of the floristic data available are georeferenced to $10 \mathrm{~km}$ UTM squares, we used these squares as mid-detail cells, and adapted the borders of the eight sectors considered to the UTM grid, in the most approximate way (Figure 1, Table 1). To study variations along the altitudinal gradient in physiography, bioclimate, and plant diversity, we analysed the sectors (and the entire area) by splitting them into narrow belts of $100 \mathrm{~m}$ altitude, from $400 \mathrm{~m}$ asl upwards. Thus, the finest spatial scale used corresponds to each small $100 \mathrm{~m}$ altitude belt within each UTM square.

There are two well-defined groups of sectors ( 2,3 and 4 vs. 5, 6 and 7), and two peripheral single sectors ( 1 and 8$)$. The first group (2, 3 and 4$)$ corresponds to the main axis and valleys of the Iberian Pyrenees, and thus it includes well-developed high mountain landscapes and is south sloping. The second group (5,6 and 7) corresponds to the proper pre-Pyrenees, which is mostly submontane and montane (with fewer high mountain landscapes), and more influenced by Mediterranean dry summers. In both groups, the eastern sectors are influenced by the Mediterranean Sea, the central-eastern area is rather continental, and the central area is sub-continental. Sector 8 is formed by the southernmost, lower ranges and surrounding depressions, and is Mediterranean to sub-Mediterranean with a rather continental influence. Sector 1 is mostly Atlantic, and includes submontane to high mountain landscapes.

We have reduced the geologic complexity of the area (mapped by ICC, 1989) into five main categories that are known to drive vegetation variation: acidic rocks (Paleozoic schist, granodio- 


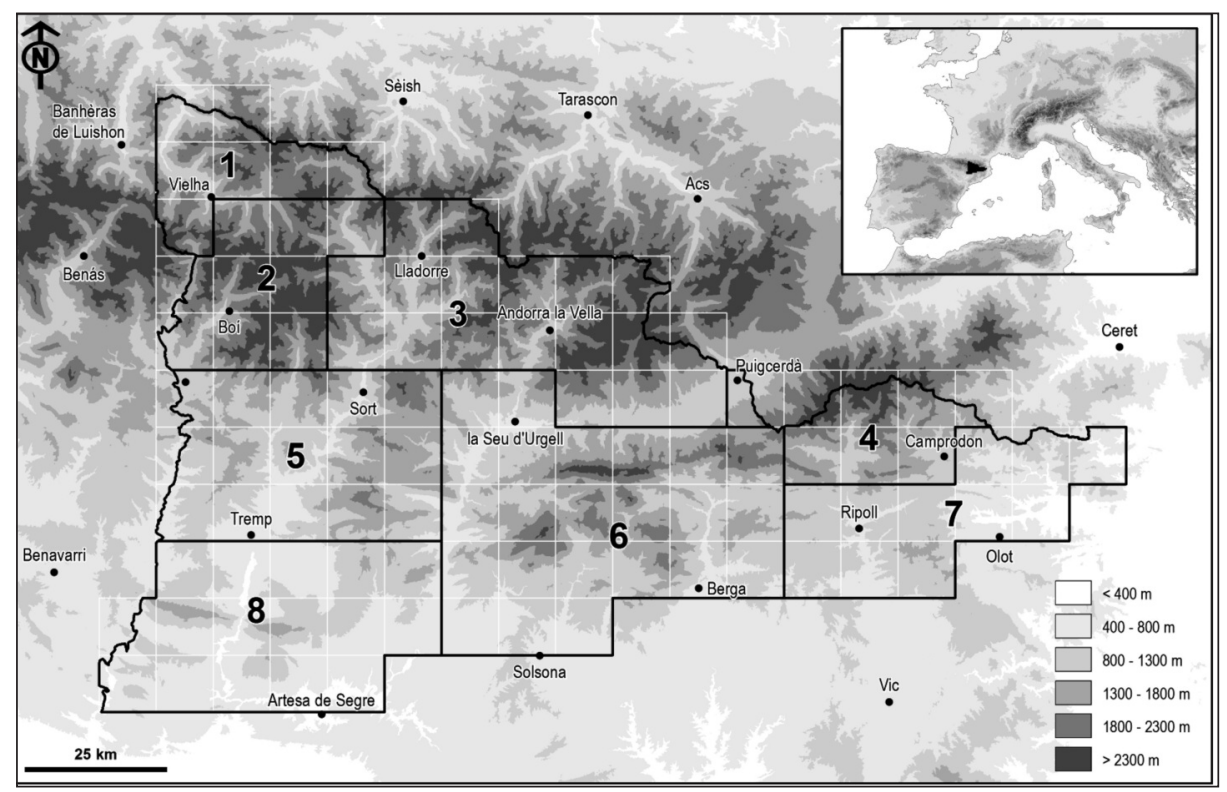

Figure 1. - Map of the study area (the Catalan and Andorran Pyrenees), divided into eight sectors according to the 10 km UTM grid: 1, Central axial Atlantic Pyrenees; 2, Central axial Iberic Pyrenees; 3, Central-Eastern axial Iberic Pyrenees; 4, Eastern axial Iberic Pyrenees; 5, Central Iberic pre-Pyrenees; 6, Central-Eastern Iberic pre-Pyrenees; 7, Eastern Iberic pre-Pyrenees; 8, Southern Iberic pre-Pyrenees (see Table 1 for a short characterization).

rite, sandstone, etc.), calcium-rich rocks (limestone, dolomite, etc.), sulphate-rich rocks, Quaternary formations, and water. To cope with the physiographic complexity, we built a digital elevation model (resolution, $20 \mathrm{~m}$ ) from topographic maps of Catalonia and Andorra (ICC, 1992 and Àres de CARTOGRAFIA, 1999). We then used the model to calculate the projection area of the sectors and belts.
The climatic approach was based on digital climatic atlases of Catalonia (NINYEROLA \& al., 2004) and Andorra (BATALLA \& al., 2011). In these highresolution digital facilities, climate variables (for instance, monthly rainfall or temperatures) are given as interpolation values among the extant measures. Then, for a given variable, we characterized each $100 \mathrm{~m}$ altitude belt in each Pyrenean sector using the mean value of the variable in the pixels

Table 1

Main physiographic features of the eight Pyrenean sectors considered

\begin{tabular}{|c|c|c|c|}
\hline Sector & $\begin{array}{l}\text { Area } \\
\left(\mathrm{km}^{2}\right)\end{array}$ & $\begin{array}{l}\text { Altitude } \\
\text { range } \\
\text { (m a.s.1.) }\end{array}$ & Main outcrops \\
\hline 1, Central axial Atlantic Pyrenees & 544 & $575-3,010$ & Acidic (slate, granodiorite: $48 \%$ ) and limestone (36\%) \\
\hline 2, Central axial Iberic Pyrenees & 827 & $875-3,029$ & Acidic (granodiorite, slate: 49 ) and limestone (26\%) \\
\hline $\begin{array}{l}\text { 3, Central-eastern axial Iberic } \\
\text { Pyrenees }\end{array}$ & 1,656 & $720-3,143$ & Acidic (slate, granodiorite: $62 \%$ ) and limestone (17\%) \\
\hline 4, Eastern axial Iberic Pyrenees & 525 & $800-2,910$ & Acidic (slate, granodiorite: $72 \%$ ) and limestone (19\%) \\
\hline 5, Central Iberic pre-Pyrenees & 1,406 & $418-2,480$ & Limestone $(81 \%)$ and acidic $(12 \%)$ \\
\hline $\begin{array}{l}\text { 6, Central-eastern Iberic pre- } \\
\text { Pyrenees }\end{array}$ & 2,299 & $437-2,649$ & Limestone $(79 \%)$ and acidic $(16 \%)$ \\
\hline 7, Eastern Iberic pre-Pyrenees & 984 & $400-1,851$ & Limestone $(86 \%)$ \\
\hline 8 , Southern Iberic pre-Pyrenees & 1,441 & $400-1,676$ & Limestone $(94 \%)$ \\
\hline
\end{tabular}


that were included. Considering the bioclimatic response to altitudinal gradient, we finally selected four bioclimatic parameters as most significant to vegetation: length of the growing period, potential evapotranspiration, mediterraneity index, and annual thermal amplitude. Length of the growing period corresponds to the part of the year in which vegetation is not thermally limited, and was defined as the number of months with a mean temperature equal to or higher than $5^{\circ} \mathrm{C}$ (following FRICH \& al., 2002). Potential evapotranspiration (PET) expresses the potential for plant growth on the basis of monthly mean temperatures, and was calculated by means of the Thornthwaite equation (Thornthwaite, 1948). Both PET and the length of the growing period are independent of hydric conditions, and thus of possible growth limitation due to climatic water stress. This driving force, which is so relevant in Mediterranean and sub-Mediterranean ecosystems, was evaluated by the mediterraneity index (RIVAS-MARTíNEZ, 2008), which measures the quotient between summer potential evapotranspiration and summer rainfall (Imed $=$ PET/P, for June, July and August). Finally, we used the annual thermal amplitude (i.e., mean temperature of the warmest month minus the mean temperature of the coldest month) as a surrogate of continentality. We assumed that at a given mean annual temperature, vegetation phenology would be strongly coupled to seasonality at higher values in thermal amplitude (RIVAS-MARTínEZ, 2008).

Landscape diversity was evaluated from the cartography of European CORINE habitats carried out for Catalonia and Andorra (CARRERAS \& al., 2001, 2012). These maps were drawn up between 1998 and 2003 from fieldwork and the observation of a minimum mapped area of approximately two hectares. We evaluated habitat richness (hereafter HR) as the number of basic CORINE habitats mapped. To assess the landscape structure, we used the nine highest-level categories in which these habitats are classified, i.e.: halophytic communities; non-marine waters; scrub; grassland; forests; bogs and marshes; inland rocks, screes and sands; agricultural land and artificial landscapes; and burned or clear-cut woodland. We used the surface occupied by each category to calculate cover percentages and habitat diversity (hereafter HD, i.e. the
Shannon index built upon the number of categories and their cover percentage).

As for plant species richness, we compiled plant catalogues for each sector. We assumed that each species occurred in the whole range encompassed by the minimum and maximum altitude at which it had been found in the sector (interpolation method; see MCCAIN \& GRYTNES, 2010). The data were retrieved from the Biodiversity Data Bank of Catalonia (BDBC; FonT, 2013), with a few additions from other sources. The final number of plant citations used was over 300,000 . These data correspond to plant observations from a wide range of papers (local flora, flora notes, or phytosociological studies), from various personal contributions, and from herbarium records. They are referenced through the corresponding altitude and 10 x $10 \mathrm{~km}$ UTM coordinates, which place each observation into squares across the whole region. Given the diverse origin of these floristic data, we considered broad species following BoLòs \& al. (2005), thus we merged subspecies and microspecies where appropriate. In addition to native species, we took into account the introduced species that have become naturalized or nearly naturalized. In addition, we modelled the distribution of Pyrenean endemics (strict endemics and subendemics, according to BoLÒs \& al., 2005) along the altitudinal gradient.

From the distribution of the entire flora, we calculated the altitudinal variation in spectra of life forms and chorotypes, which were attributed to each species following the proposals stated in BoLòs \& al. (2005) after some simplification. In the case of chorotypes, we considered the following: Mediterranean (endemic to the region, but not particularly related to mountain areas), oroMediterranean (or Mediterranean orophytes), sub-Mediterranean (typical of transitional landscapes from medio-European to Mediterranean), Atlantic, medio-European, Alpine (found in the Alps and similar mountains), Boreo-Alpine (disjunct, in boreal latitudes and in Alpine mountains), Pyrenean (endemics and sub-endemics), pluriregional, and introduced.

In a similar way, we calculated the altitudinal variation in ecological preferences of Pyrenean flora. Following previous papers (NINOT \& 
FERRÉ, 2008; NINOT \& al., 2010), we attributed each species to one of six broad categories, by simplifying the ecological and phytosociological information given in general floristic and vegetation papers (Bolòs \& al., 2005; VILlaR \& al., 1999-2001, etc.):

Forests: taxa that clearly prefer forest ecosystems, though sometimes also occur in serial communities

Scrubs and clearings: plants with ecological optimum in shrubby communities or in the vegetation of forest clearings and hedges, though they sometimes also occur in forests or pastures.

Grasslands: plants showing a clear preference for these herbaceous units, excluding those with ruderal tendency. From lowlands to the subalpine belt, they form secondary vegetation related to deforestation, or permanent units on rocky slopes, whereas in the alpine belt they mainly inhabit the most balanced habitats (flat areas and gentle slopes).

Ruderal habitats: taxa that mainly occur in fields, fallows, roadsides and other places subject to disturbance.

Water-related habitats: plants restricted to streamsides, springs or other habitats that are more humid than the zonal areas (such as certain northfacing toeslopes or cliffs). We included here hygrophilous forests, associated bramble units, rush formations, and fens.

Rocky habitats: taxa occurring on rocks (crevices, rocky shelves), scree and other rocky places; as well as halophilous and gypsophilous taxa.

Finally, we assessed the relationships among the eight sectors according to the descriptors of their particular plant diversity, namely the number of habitats, plant species and endemics, and the species percentages of life-forms, habitat preferences and chorotypes. This was done by means of a Principal Component Analysis (PCA) performed from the Ginkgo package (DE CÁCERES, 2012).

\section{RESULTS}

\section{ABIOTIC FACTORS AND LANDSCAPE STRUCTURE}

The distribution of the projected area along the altitudinal gradient was rather heterogeneous among sectors (Figure 2, up). In the axial Pyrenees, the western sectors (1 and 2) were mostly subalpine and alpine, and included smaller areas of lower altitudinal belts. The eastern sector showed an opposite trend, whereas the area in the centraleastern sector was evenly distributed from the submontane to the alpine belts. In the pre-Pyrenees, sectors 5 and 6 included similarly large areas of basal, submontane and montane belts, whereas sectors 7 and 8 showed a less regular pattern, with greater development of the submontane and basal belts, respectively. In all cases, the very small areas included in most of the upper and lower ends of the gradients reduced the significance of the ends of the altitudinal patterns further analyzed, in terms of causal factors and plant diversity.

Regarding substrata diversity, the Shannon index is higher in the axial Pyrenees than in the pre-Pyrenees, both in mean figures ( 1.42 vs. 0.85 respectively) and in specific values for most of the altitudinal gradient of the distinct sectors (Figure 2 down). The higher values in the axial Pyrenees are due to a more even distribution of the extant substrata, since the pre-Pyrenees include a higher number of substrata types. For instance, gypsum outcrops are exclusive to three of the four pre-Pyrenean sectors, where they promote particular (though species-poor) vegetation units. Calcium-rich substrata were dominant in the entire study area (61.4\% of the outcrops compared to $27.4 \%$ of acidic outcrops). They were particularly predominant in the pre-Pyrenees $(85.0 \%)$, where calcareous rocks were the only category at the highest elevations of most sectors (6,7 and 8). In contrast, acidic rocks occupied large areas in the axial Pyrenean sectors (57.9\%) and were the only outcrop category near to the summits (in combination with glacial Quaternary deposits derived from these same acidic rocks; Table 1).

Most bioclimatic parameters had regular monotonic patterns that linearly decreased or increased with altitude, and roughly followed the general thermal altitudinal gradient, in which temperatures have been found to decrease $0.58^{\circ} \mathrm{C}$ for each 100 $\mathrm{m}$ of increasing altitude (NINOT, 1998). For instance, the growing period lasted 9.5-10 months at pre-Pyrenean lower altitudes (but 12 months in the lowlands of the eastern, maritime sector), and de- 


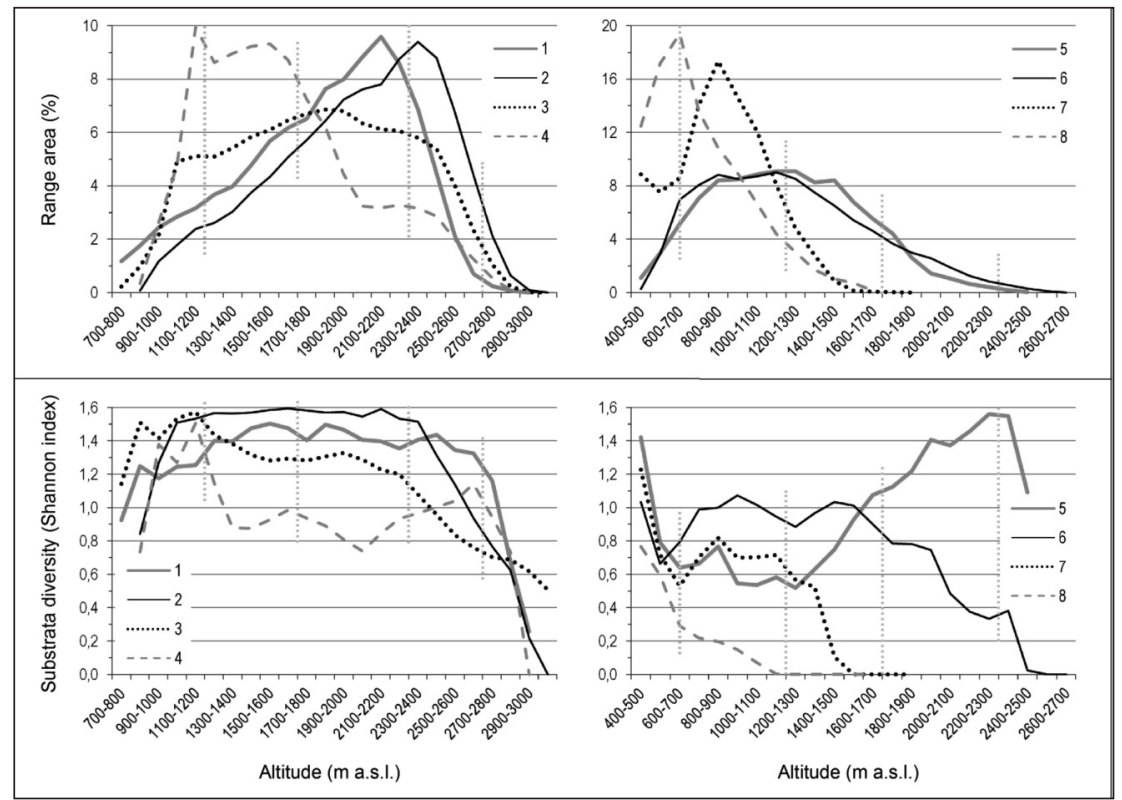

Figure 2. - Altitudinal variation of physiographic aspects (range area and substrate diversity) in the study area. The left graphs correspond to the axial Pyrenean sectors (1-4) and the right graphs to the pre-Pyrenean sectors (5- 8). See Table 1 and Figure 1 for the characterization and location of these sectors. Vertical dotted lines indicate the mean altitude for shifts between vegetation belts (i.e., basal, submontane, montane, subalpine, alpine, subnival).

creased regularly through the different sectors to only 3 months at 3,000 $\mathrm{m}$ asl in the higher axial Pyrenees (Figure 3 up). Thus, the growing period equalled the cold resting period at the transition between the montane and subalpine belts $(1,600-1,800$ $\mathrm{m}$ asl), and amounted to $4-5$ months at the potential treeline (i.e., at about 2,300-2,400 m asl, depending on sectors). Sector 7, which is the easternmost prePyrenean sector, stands out among all the sectors for its milder thermal conditions at low altitudes throughout the cold period. As a result, it has a longer (1 to 1.5 months) growing period in the submontane and montane belts (up to some 1,400 m asl) compared with most sectors. In contrast, sector 1 had a slightly shorter growing period than the other axial Pyrenean sectors from the mid-montane to the mid-subalpine belts (1,300-1,900 m asl).

Potential annual evapotranspiration (PET) was evaluated as $720-740 \mathrm{~mm}$ at the pre-Pyrenean lower altitudes (data not shown), and progressively decreased upslope, while annual rainfall increased. As a general trend through the sectors, PET decreased lineally to $590-630 \mathrm{~mm}$ at $1000 \mathrm{~m}$ asl and down to $355-360 \mathrm{~mm}$ at $3000 \mathrm{~m}$ asl. Since annual rainfall accounted for $500-700 \mathrm{~mm}$ in most of sector 8 and for $600-700 \mathrm{~mm}$ in noticeable areas of sectors 5 and 6, higher PET values reveal clear Mediterranean conditions in these low altitude areas. Annual PET values were slightly lower in the submontane belt of the axial Pyrenean sectors than in the pre-Pyrenean sectors, but differences among sectors were very small in the montane belt and above. However, sector 1 showed slightly lower values than the other axial Pyrenean sectors, particularly at the submontane, montane and subalpine belts (mean $=30 \mathrm{~mm}$ in annual PET).

The mediterraneity index (quotient between PET and rainfall during summer) also decreased with altitude, more or less in parallel in all sectors (Figure 3, middle). However, this decrease was not as regular as that of other bioclimatic descriptors, and there were noticeable differences among sectors. For instance, in the easternmost Pyrenean sector the index remained below 1 (i.e., denoting no water stress) even at lower altitudes. In the other axial Pyrenean sectors (including Val d'Aran, with strong atlantic influence) it was above 1 until the transition from the montane to the subalpine belts (1,600-1,800 m asl), and showed some altitudinal irregularities in the submontane and 


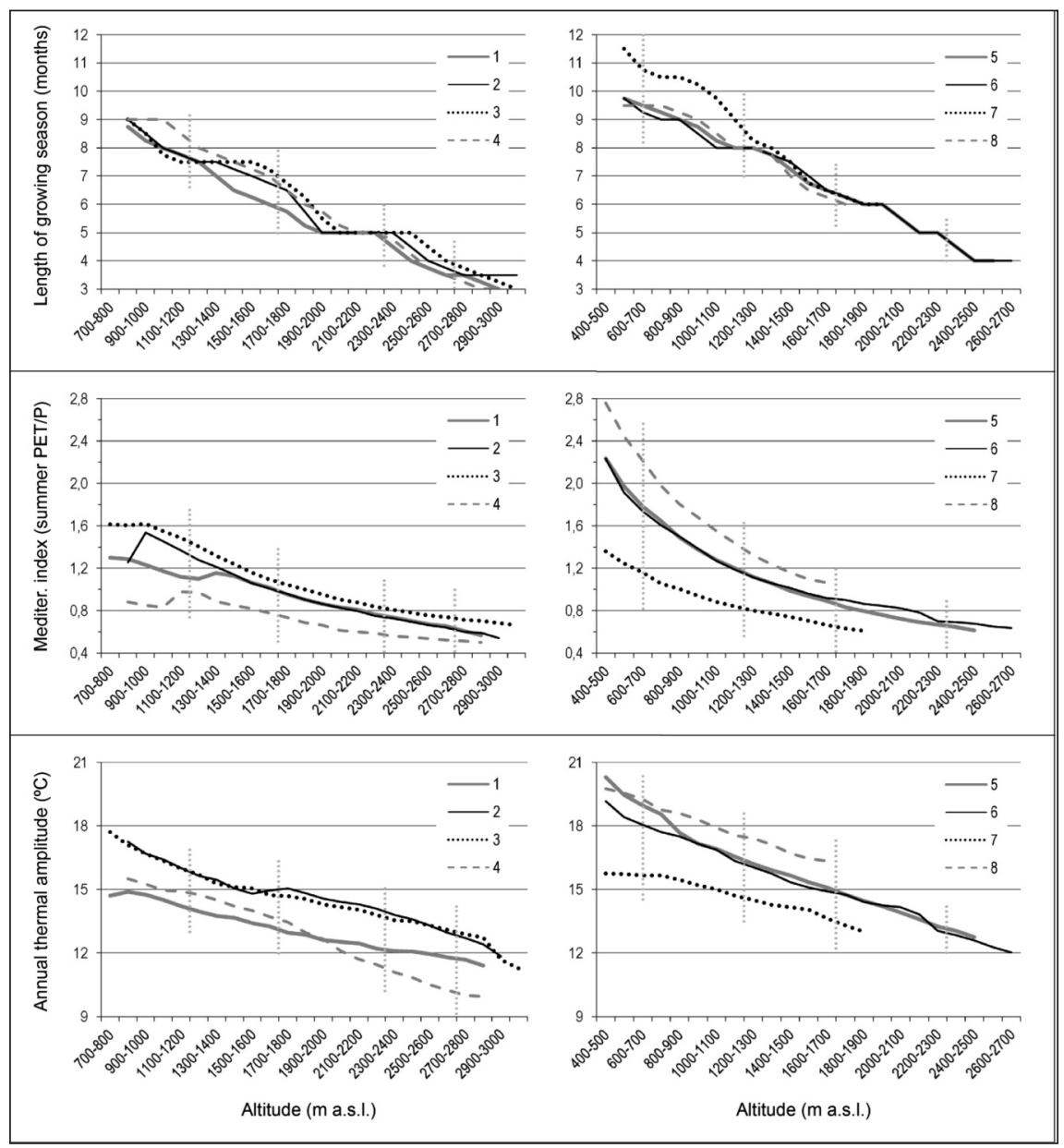

Figure 3. - Altitudinal variation in bioclimatic descriptors in the area studied. The left graphs correspond to the axial Pyrenean sectors (1-4) and the right graphs to the pre-Pyrenean sectors (5-8). Vertical dotted lines indicate the mean altitude for shifts between vegetation belts.

montane belts. All the pre-Pyrenean sectors had a water deficit at lower altitudes, where this climatic parameter followed an exponential trend with decreasing altitude, and reached stress values. Namely, in all the pre-Pyrenean sectors except the eastern one, summer water shortage was very pronounced at the lowest altitudes ( $400 \mathrm{~m}$ asl), where PET amounted to 2.2-2.8 times the rainfall. Differences among these sectors were greater than among the axial Pyrenean ones. As extreme prePyrenean cases, water deficit occurred only until $900 \mathrm{~m}$ a.s.l. in the eastern sector, whereas in sector 8 (the southern pre-Pyrenees) it took place up to the summits $(1,600-1,700 \mathrm{~m}$ asl). In other aspects, the eastern sectors ( 4 and 7 ) had lower mediterraneity indexes than the other sectors throughout the altitudinal gradient (in spite of being closest to the Mediterranean Sea). This must be related to more orogenic rainfall events in summer near the Mediterranean coast than inland, and to slightly lower temperatures.

Continentality, estimated as annual thermal amplitude, also decreased regularly with altitude in all sectors (Figure 3, down). The Atlantic (1) and the eastern (4) axial sectors were less continental than the others. They showed a complementary trend, since sector 1 was the most oceanic in the submontane and montane belts, whereas sector 4 held this place in the high mountain. The PrePyrenees had slightly higher thermal amplitudes in general. Only the eastern sector (7) had moderate amplitudes across the altitudinal gradient, 
whereas in the other sectors the submontane belt (and part of the montane belt) may be considered semicontinental (i.e., with a thermal amplitude higher than $17^{\circ} \mathrm{C}$; Rivas-Martínez, 2008).

Our analysis showed that most of the Pyrenean landscape is covered by natural and seminatural vegetation, i.e. forests, scrubs and extensive pastures. Woodland is the most extensive unit in most sectors, particularly in sectors 6 and 7. Anthropic units (fields, farms and villages) occupy small areas of up to $9 \%$, except in pre-Pyrenean sector 8 , where they account for $22.5 \%$ (Figure 4). Grassland areas are relevant in general, though they decrease from the axial Pyrenees to the pre-Pyrenees, and from western to eastern sectors (Figure 4). Within each sector, they occupy at least $5 \%$ of the area along the altitudinal gradient (the ends of the gradient were not considered), and become more dominant with altitude (Figure 5, up). They reach values between $20 \%$ and $40 \%$ in the montane belt (or even in the submontane), and above $40 \%$ in the high-subalpine and alpine belts (not in sectors 7 and 8, which do not include these landscape levels).

There was high habitat richness, with an HR value of 219 for the entire study area. The average HR value for the sectors was 117 , with sector 7 holding the minimum and sector 6 the maximum values (90 and 148, respectively; see Table 2). The average HR was higher in the pre-Pyrenean sectors (121) than in the axial Pyrenean sectors (113), while the average Shannon index pattern was the opposite (pre-Pyrenean sectors $=4.95$; Pyrenean sectors $=5.20$ ). This indicates a more even distri- bution of habitats in the axial Pyrenees, which is a similar trend found in the substrate distribution.

As expected, HD decreased in altitude from low-medium altitudes upwards (Figure 5 down), which reflected more a decrease in HR than in habitat evenness (Pielou's J; data not shown). In sectors 7 and 8 (those which do not include high mountain), the decrease started at lower altitudes, along the montane belt upwards. In most of the other sectors, HR and HD reached the highest values in the montane belt, and were only slightly lower in the submontane belt. However, sector 1's pattern in the montane belt was the inverse of that found in the other axial Pyrenean sectors. Thus, a partial minimum at $1,400-1,700 \mathrm{~m}$ gave a $20 \%$ lower HR than sector 2, despite their physiographic similarities (Table 1; Figure 2). In most sectors, the decreasing trend was greater in the subalpine belt, and became sharper towards the alpine and the basal belts.

\section{PlANT DIVERSITY}

The flora recorded in the whole study area accounted for 2,335 vascular plant species. The local species richness showed great variation among sectors, with no clear relation with their size (Tables 1 and 2). In fact, the logarithmic relationship between species richness and area size across sectors (LOMOLINO, 2000) gave a very weak correlation $\left(\mathrm{R}^{2}=0.23\right.$, results not shown). Moreover, no clear relation was found between species richness and altitudinal span or maximum altitude. Sectors

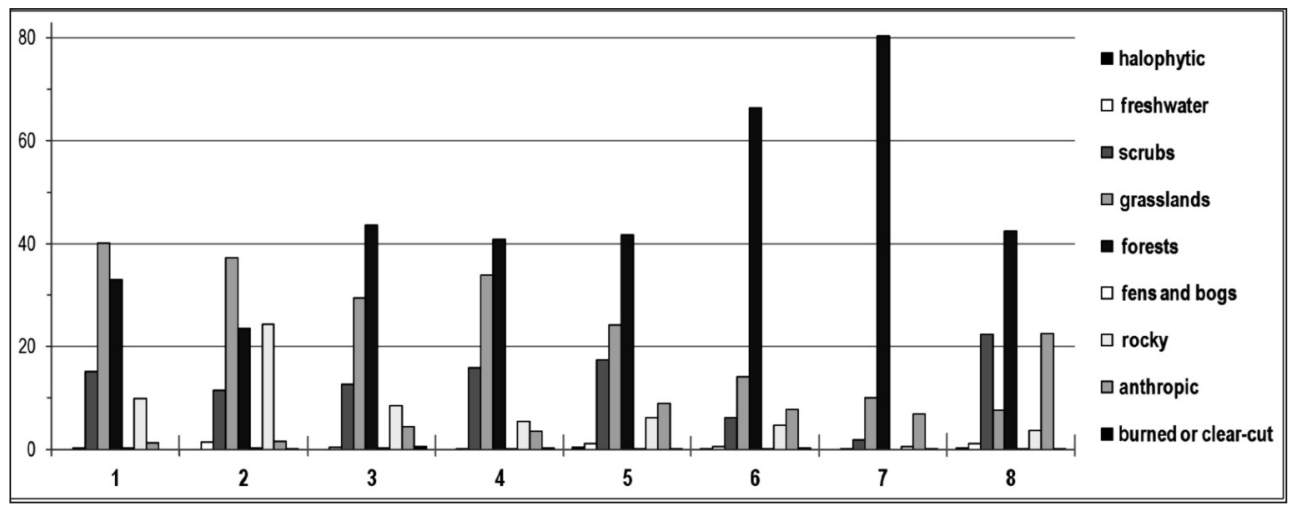

Figure 4. - Relative cover (percentage) of the main habitats found in the eight sectors, according to the CORINE highest types. See Table 1 and Figure 1 for the characterization and location of these sectors. 


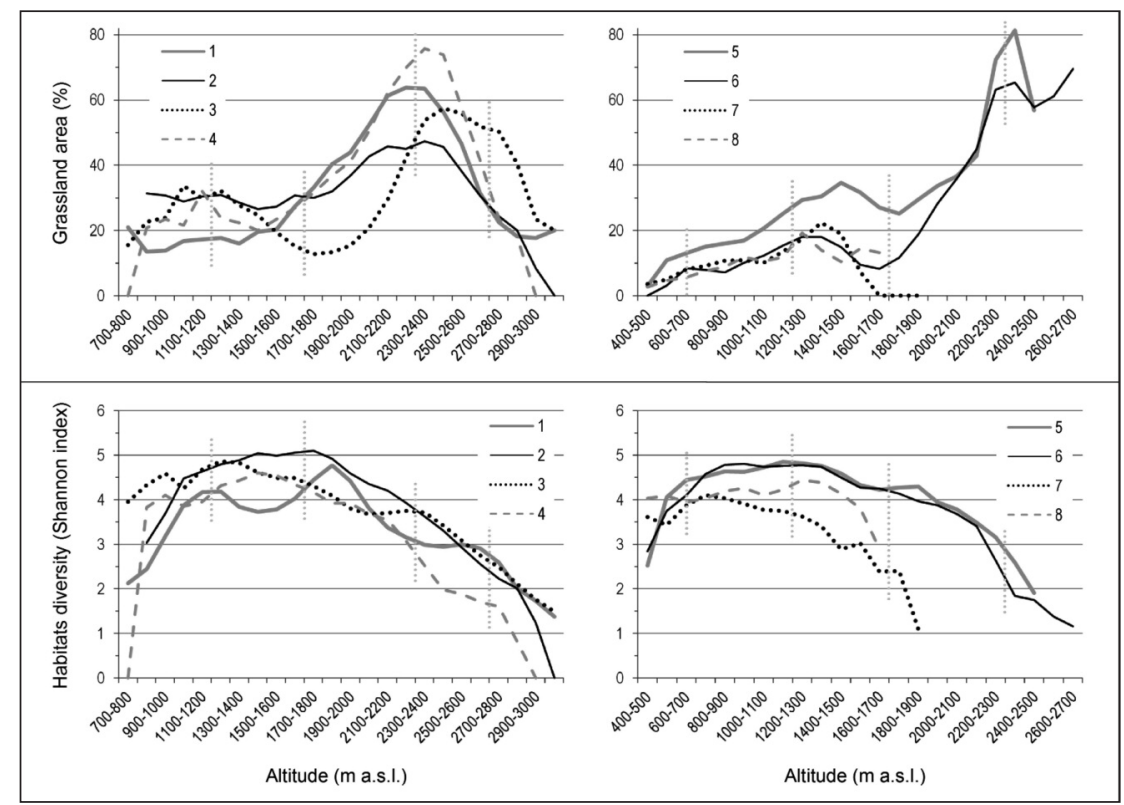

Figure 5. - Altitudinal variation in percentage of grassland areas (up) and in diversity of landscape units (down). The left graphs correspond to the axial Pyrenean sectors (1-4) and the right graphs to the pre-Pyrenean sectors (58). Vertical dotted lines indicate the mean altitude for shifts between vegetation belts (i.e., basal, submontane, montane, subalpine, alpine, subnival).

4 and 6 were clearly richer than expected after their area, and sectors 1 and 8 poorer. The species richness responded better to HR (similarly as a lineal or as a logarithmic correlation; Figure 6), since richer sectors ( $4 \& 6$ ) and poorer sectors (1 \& 8) became less distinct. As for the endemic flora, its richness was clearly not correlated to the area size and very weakly to $H R\left(R^{2}=0.003\right.$ and 0.25 respectively, results not shown).

The flora of the sectors considered showed also interesting variations in their spectra of life forms, preference for main habitats, and chorotypes (Table 2). For instance, the higher percentages of evergreen phanerophytes and therophytes, and the lower percentages of hemicryptophytes differentiated the pre-Pyrenean sectors (and particularly sector 8) from the axial Pyrenean sectors. Concerning ecological preferences, higher percentages of scrub flora and lower of water-related species were also singular for the pre-Pyrenean sectors. Moreover, the flora of sector 8 included clearly higher percentage of ruderal species and lower percentage of forest species. As for the distribution of local floras into chorotypes, the pre-Pyrenean areas were richer in Mediterranean taxa and poo- rer in Boreo-Alpine, Alpine and Pyrenean species. More particular differences with respect to the mean values made sector 8 the most distinct (less Alpine and more Mediterranean and Pluriregional), and sectors 1 (more medio-European, less Mediterranean) and 7 (more medio-European, less Alpine and Pyrenean) rather singular.

The altitudinal variation in species richness obtained by interpolation showed a very marked humped response in all the sectors (Figure 7 up). The pattern was more or less asymmetric in the different cases, since species richness increased fast from the lowest altitudes upwards to reach wide maxima in the montane (or submontane) belt, and then decreased towards the summits, in most cases less sharply than it increased at lower altitudes. Axial Pyrenean sector 1 and pre-Pyrenean sectors 5 and 6 gave a similar pattern, characterized by less asymmetry and maxima plateaus peaking in the montane belt $(1,200-1,700$ $\mathrm{m}$ asl). Axial sectors 2 and 3 peaked in the montane belt, while sectors 4 and 7 reached their maxima in the submontane belt, and sector 8 peaked in the transition between the basal and submontane belts $(600-700 \mathrm{~m}$ asl). 


\section{Table 2}

Main plant diversity descriptors of the eight sectors, mean values (and standard deviation) through the sectors, and global values for the whole study area.

The figures in the section Richness correspond to number of habitats, species and endemics; and those in the sections Life forms, Main habitats, and Chorotypes are species percentages in the corresponding floras.

\begin{tabular}{|c|c|c|c|c|c|c|c|c|c|c|}
\hline & 1 & 2 & 3 & 4 & 5 & 6 & 7 & 8 & Mean & Whole \\
\hline \multicolumn{11}{|l|}{ Richness } \\
\hline Habitats richness & 96 & 117 & 134 & 103 & 135 & 148 & 90 & 112 & $117 \pm 20.6$ & 219 \\
\hline Total species richness & 1,220 & 1,487 & 1,579 & 1,506 & 1,448 & 1,698 & 1,347 & 1,251 & $1,442 \pm 146.6$ & 2,335 \\
\hline Pyrenean endemics richness & 57 & 67 & 67 & 54 & 47 & 63 & 21 & 22 & $50 \pm 18.7$ & 97 \\
\hline \multicolumn{11}{|l|}{ Life forms } \\
\hline Evergreen Phanerophytes & 0.9 & 1.0 & 1.8 & 1.5 & 2.0 & 2.7 & 3.2 & 3.5 & $2.1 \pm 0.97$ & 2.7 \\
\hline Deciduous Phanerophytes & 7.0 & 6.5 & 6.8 & 6.6 & 6.8 & 6.3 & 7.9 & 7.0 & $6.9 \pm 0.48$ & 5.6 \\
\hline Chamaephytes & 14.7 & 13.7 & 12.9 & 13.2 & 12.8 & 12.8 & 11.4 & 12.7 & $13.0 \pm 0.94$ & 13.0 \\
\hline Geophytes & 9.0 & 8.7 & 8.0 & 9.4 & 8.4 & 8.9 & 10.5 & 8.3 & $8.9 \pm 0.78$ & 9.5 \\
\hline Hydrophytes & 1.6 & 2.1 & 1.8 & 1.1 & 1.4 & 0.9 & 1.1 & 1.2 & $1.4 \pm 0.41$ & 2.0 \\
\hline Hemicryptophytes & 53.3 & 51.6 & 50.3 & 49.7 & 46.2 & 46.8 & 46.5 & 39.0 & $47.9 \pm 4.43$ & 44.8 \\
\hline Therophytes & 13.6 & 16.4 & 18.4 & 18.5 & 22.4 & 21.7 & 19.5 & 28.2 & $19.8 \pm 4.39$ & 22.5 \\
\hline \multicolumn{11}{|l|}{ Main habitats } \\
\hline Forests & 11.1 & 9.2 & 8.7 & 9.4 & 8.5 & 8.3 & 10.9 & 7.4 & $9.2 \pm 1.27$ & 7.6 \\
\hline Scrubs & 13.4 & 12.6 & 13.3 & 12.4 & 14.6 & 14.2 & 15.7 & 16.2 & $14.1 \pm 1.39$ & 13.8 \\
\hline Grasslands & 33.0 & 32.0 & 31.2 & 30.6 & 31.1 & 30.1 & 28.4 & 29.7 & $30.8 \pm 1.42$ & 29.1 \\
\hline Ruderal & 12.7 & 17.5 & 18.7 & 20.8 & 22.4 & 22.9 & 22.9 & 27.1 & $20.6 \pm 4.34$ & 21.5 \\
\hline Water-related & 16.3 & 15.5 & 15.6 & 14.7 & 12.8 & 12.4 & 13.3 & 9.8 & $13.8 \pm 2.15$ & 15.4 \\
\hline Rocky & 13.5 & 13.2 & 12.4 & 12.0 & 10.6 & 12.1 & 8.7 & 9.8 & $11.5 \pm 1.68$ & 12.6 \\
\hline \multicolumn{11}{|l|}{ Chorotypes } \\
\hline Mediterranean & 5.6 & 10.3 & 11.9 & 11.7 & 19.5 & 17.6 & 18.6 & 29.0 & $15.5 \pm 7.22$ & 20.0 \\
\hline Oro-Mediterranean & 3.8 & 3.8 & 3.3 & 3.2 & 4.0 & 3.9 & 2.6 & 4.4 & $3.6 \pm 0.56$ & 3.8 \\
\hline Sub-Mediterranean & 3.6 & 5.0 & 4.9 & 4.8 & 5.9 & 5.2 & 5.3 & 6.7 & $5.2 \pm 0.89$ & 4.3 \\
\hline Atlantic & 3.3 & 2.2 & 2.0 & 1.7 & 1.0 & 1.2 & 2.2 & 0.6 & $1.8 \pm 0.85$ & 2.4 \\
\hline Medio-European & 37.9 & 33.1 & 33.0 & 34.4 & 30.5 & 30.2 & 35.3 & 24.5 & $32.3 \pm 4.04$ & 27.2 \\
\hline Boreo-Alpine & 12.5 & 10.7 & 9.8 & 9.3 & 5.1 & 6.6 & 4.7 & 1.5 & $7.5 \pm 3.67$ & 7.9 \\
\hline Alpine & 12.0 & 10.2 & 9.2 & 8.6 & 5.2 & 6.7 & 3.9 & 1.0 & $7.1 \pm 3.62$ & 6.9 \\
\hline Pyrenean & 4.7 & 4.5 & 4.2 & 3.6 & 3.2 & 3.7 & 1.6 & 1.8 & $3.4 \pm 1.17$ & 4.2 \\
\hline Pluriregional & 15.5 & 17.9 & 18.8 & 18.9 & 22.1 & 20.6 & 21.6 & 27.0 & $20.3 \pm 3.44$ & 18.8 \\
\hline Introduced & 1.3 & 2.4 & 2.8 & 3.7 & 3.5 & 4.4 & 4.1 & 3.6 & $3.2 \pm 1.01$ & 4.5 \\
\hline
\end{tabular}

The endemic flora (Figure 7 down) gave also a humped response along the altitudinal gradient, but with respect to the whole flora, the endemics showed a somewhat symmetric pattern, with a moderate increase and sharper decrease along the gradient and with maxima at higher altitudes, well in the subalpine belt. This pattern is clearer for the axial Pyrenees (with a clear maximum at 2,200-2,300 $\mathrm{m}$ asl) than for pre-Pyrenees (with maximum at 2,000-2,100 $\mathrm{m}$ asl, and submaxima at lower altitudes).

The relative proportion of the distinct life forms in the Pyrenean flora showed varying trends along altitude. Hemicryptophytes made the biggest group through the altitude and the axial Pyrenean or prePyrenean sectors (38-65\%; Figure 8 up). They showed a general increasing trend with increasing altitude for most of the gradient, excluding the lowest altitudes and the alpine belt. Therophytes made high proportions in the submontane belt (23$28 \%$ ) and decreased regularly up to the highest altitudes, together with phanerophytes. Geophytes, hydrophytes and chamaephytes maintained low representation through most of the gradient, but while geophytes and hydrophytes clearly decreased and eventually disappeared from mid subal- 


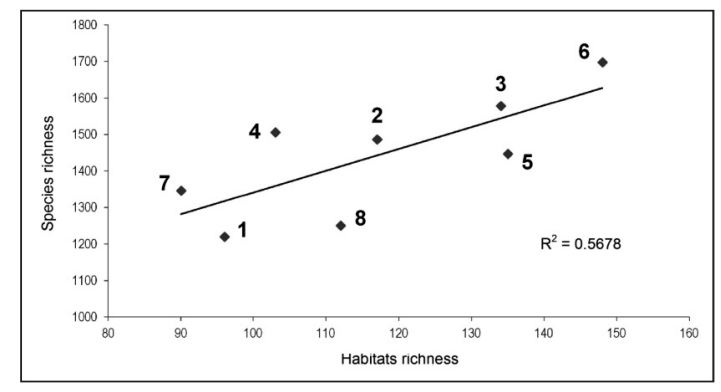

Figure 6. - Correlation between species richness and habitats richness in the sectors considered. See Figure 1 and Table 1 for their location and characterization.

pine belt to the summits, chamaephytes increased along the high mountain and reached a high percentage towards the summits (>30\%).

As for habitat preferences (Figure 8, middle) forests and scrubs hosted low to moderate percentages of the flora from low altitudes to mid subalpine belt (9-10\% in the axial Pyrenees and $14-16 \%$ in the pre-Pyrenees, for most intervals), with very little variations along altitude, and between axial Pyrenees and pre-Pyrenees. In the same altitudinal range, grassland areas included many more plant species $(26-34 \%)$ and then showed an increasing trend along the subalpine belt. From there upwards, whereas species richness in forest and scrub decreased gradually, grassland species increased up to $50 \%$ of the flora (and to more than $63 \%$ in the reduced areas near the summits). The ruderal flora was very rich in the submontane belt (22-28\%) and gradually decreased in altitude, although it remained noticeable (4-5\%) up to the lower alpine belt. Particular habitats related to water or to rocky outcrops hosted moderate species percentages up to $2,000 \mathrm{~m}$ asl $(10-19 \%$ in the axial Pyrenees and 8-18\% in the pre-Pyrenees), and showed inverse shifts towards the summits; whereas hygrophilous species clearly decreased, species richness in rock and scree habitats showed a rising trend and accounted for more than $25 \%$ of the summit floras.

The chorotypes considered showed monotonic trends -with increasing or decreasing percentages-along the altitudinal gradient, although most of them remained with some representation even at their less favourable end (Figure 8, down). Mediterranean flora (excluding Mediterranean orophytes) accounted for low to moderate per-

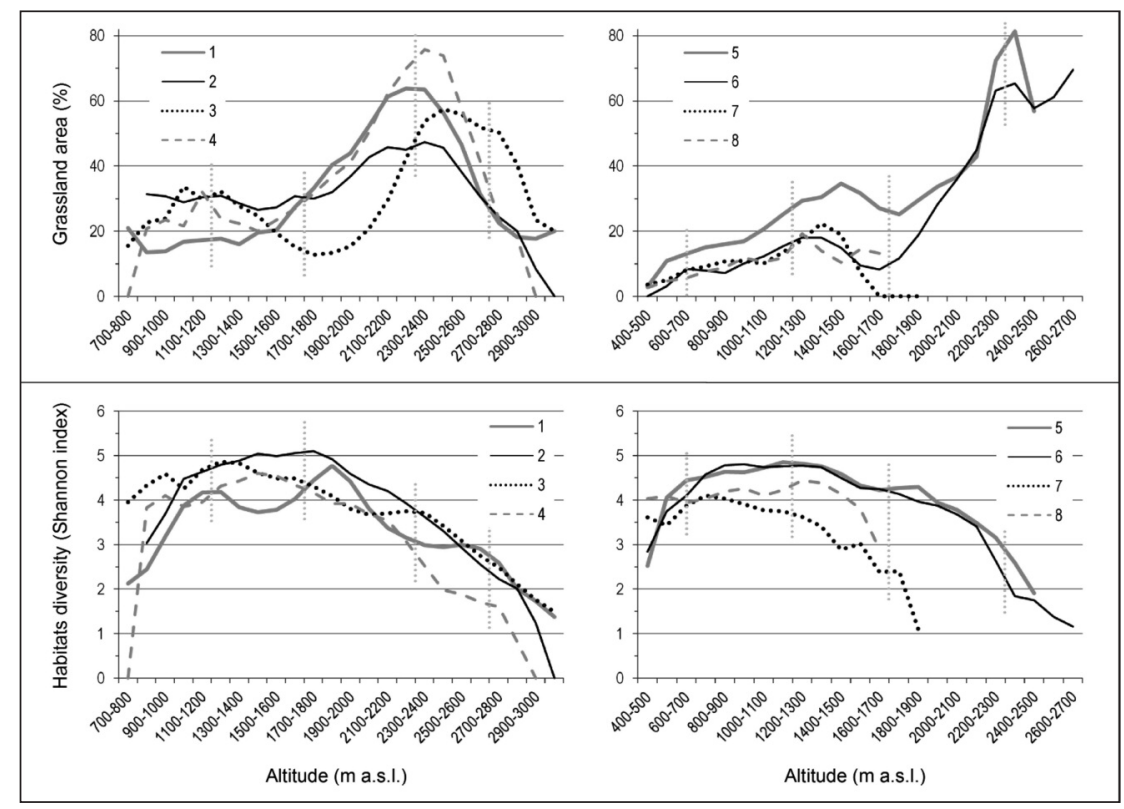

Figure 7. - Altitudinal variation in plant species richness in the eight sectors (up) and Pyrenean endemics richness in the axial Pyrenees and the pre-Pyrenees (down). The left graphs correspond to the axial Pyrenees and the right graphs to the pre-Pyrenees. Vertical dotted lines indicate the mean altitude for shifts between vegetation belts (i.e., basal, submontane, montane, subalpine, alpine, subnival). 


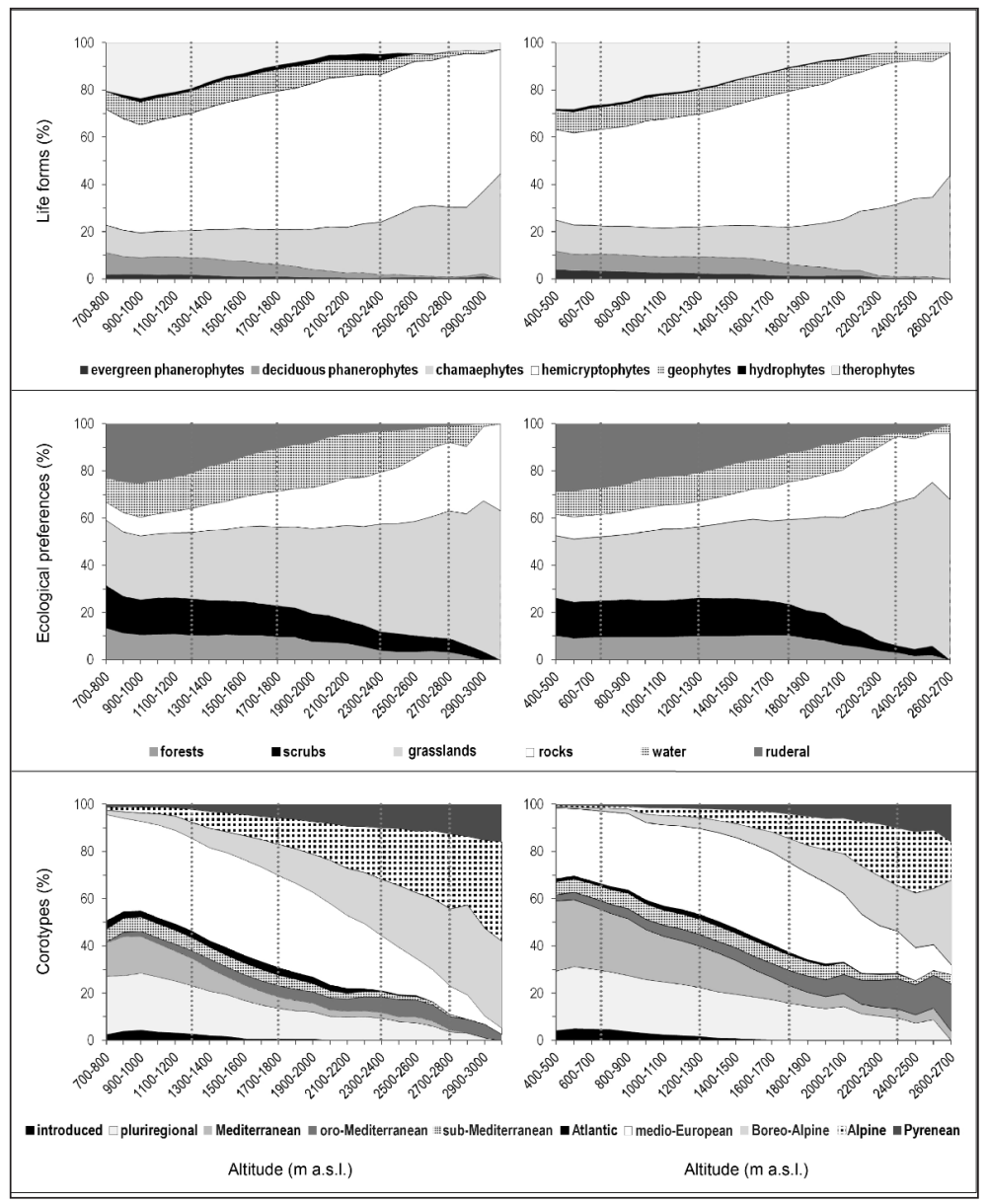

Figure 8. - Altitudinal variation in the spectra of life forms (up), ecological preferences (middle) and chorotypes (down) of the flora in the area studied. The left graphs correspond to the axial Pyrenees (total data for sectors 1-4) and the right graphs to the pre-Pyrenees (sectors 5- 8). Vertical dotted lines indicate the mean altitude for shifts between vegetation belts (i.e., basal, submontane, montane, subalpine, alpine, subnival).

centages at the basal and submontane belts (5$17 \%$ in the axial Pyrenees and $19-30 \%$ in the prePyrenees) and decreased gradually up to the summits, where a few examples were still found even in the axial sectors. Oro-Mediterranean, sub-Mediterranean and Atlantic taxa were small parts of the flora across the whole gradient. However, whereas Atlantic species disappeared along the alpine belt, Mediterranean orophytes increased variously, and reached noticeable percentages (10-14\%) at the pre-Pyrenean higher altitudes. The medio-European flora was the largest chorotype of the flora in the submontane and montane belts (38-45\% in the axial Pyrenees and $29-39 \%$ in the pre-Pyrenees). In parallel with Mediterranean and pluriregional chorotypes, medio-European chorotype decreased from mid subalpine belt upwards, and reached the summits by means of a few species. Opposite to this trend, Boreo-Alpine, Alpine and Pyrenean species percentages gradually increased from the lowest altitudes to the summits; in the axial Pyrenees these three chorotypes became especially dominant in the high alpine and subnival belts.

The plant diversity descriptors of Table 2 revealed strong correlation among them through the eight sectors; over one third of the total of pairs had higher values than 0.7. For the PCA we used a logical selection of eight descriptors showing lower correlation values among them, which led 
to the space ordination of sectors and descriptors shown in Figure 9. The pre-Pyrenean sectors 7 and 8 and the Atlantic sector 1 show particular, peripheral locations, due to their distinctiveness in different aspects (plant richness, life-forms, floristic preferences for habitats, and chorotypes). Also, a number of the descriptors (mostly correlated with axis 1) draw a general distinction between axial sectors (which are relatively clustered in the left lower part) and pre-Pyrenean sectors (which are more dispersed over the rest of the field).

\section{DISCUSSION}

Most of the abiotic differences between sectors lay in the location of each sector within the Pyrenees, which defines its altitudinal span, main outcrops, physiography and bioclimate. The distribution of the projected area along the altitudinal gradient gives some basic differences between axial and pre-Pyrenean sectors. Namely, the pre-Pyrenean sectors include a high proportion of submontane and basal belts, and little or no alpine belt. This must be the cause of the bulk floristic differences in the spectra of life forms, the preference for main habitats, and the chorotypes between both groups of sectors (Mark \& Dickinson, 2000; DE Bello \& al., 2013). For instance, the pre-Pyrenean sectors host high percentages of evergreen phanerophytes and therophytes, which are good strategies to thrive under the Mediterranean influence (Thompson, 2005; NinOt \& Ferré, 2008) and lower percentages of hemicryptophytes. This is particularly clear for sector 8 , where a greater development of the basal belt has led to larger anthropic landscapes and less forest diversity. In turn, this has produced a higher percentage of ruderal species and a lower percentage of forest species.

Species richness and habitat richness are poorly correlated with the direct abiotic variables of the sectors, and even with basic combinations of them (such as the combination of total projected area, altitudinal span and landscape diversity). In fact, despite the strong similarity in physiographic descriptors between sectors 1 and 2, and between sectors 5 and 6 , there were strong differences in species richness (and in endemics richness; Table 2 and Figure 6) within each pair. Thus, species and habitat richness seem to be the result of more complex combination of factors, at least at the scale of the sectors analysed here. Moreover, the relative poorness of sectors 7 and 8 , and their distinctiveness in terms of chorotypes, are mostly due to the lack of high mountain, and thus to the poor representation of flora related to altitude. In addition, the floristic singularity of the sectors, measured as the richness in Pyrenean endemics, reflected the relative differentiation between them and the neighbouring non-Pyrenean areas. In this aspect, sectors 7 and 8 have a transitional character between the Pyrenees and non-Pyrenean mountains. Their plant diversity is partly related to that of the other Pyrenean sectors due to vicinity and to similarities in the lower belts, and partly similar to that of coastal Catalanidic mountains due to similarities in physiographic aspects -and thus poorness in orophytes and in Pyrenean endemics. Thus, and coinciding with floristical approaches (BoLÒs \& VIGO, 1984; LóPEZ \& FONT, 2006) our analysis shows the transitional phytogeographic character of the southernmost Pyrenean ranges (sector 8) and southeastern Pyre-

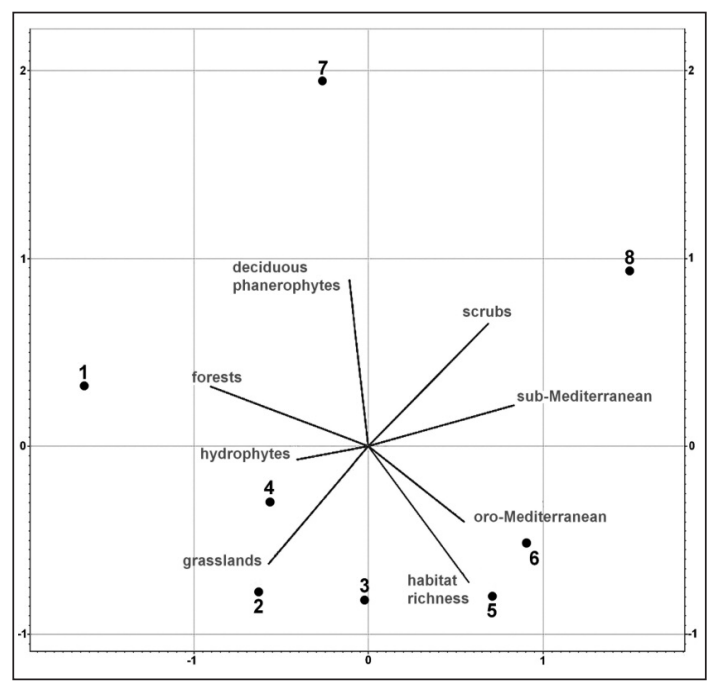

Figure 9. - Ordering of the sectors (numbered dots) in a space defined by the two first axes (loading $39 \%$ and $30 \%$ of the total variance) of a Principal Component Aanalysis based on the values of eight descriptors of plant diversity from Table 2 . 
naean mountains (sector 7), between the true Pyrenees and the Catalanidic mountains.

The relationships among sectors illustrated in Figure 9 helps in relating their floristic content to their abiotic particularities. Clearly, the peripheral situation of sectors 1,7 and 8 reflects their physiographic and bioclimatic distinctiveness, which in turn is the result of their peripheral locations within the area studied. In addition, the location of sectors 1 and 7 towards the upper right of the space may be related to their more oceanic character (chiefly through higher values in forest and medio-European flora). Overall, the differentiation in plant diversity between sectors is due to basic differences in their altitudinal span (e.g., the lack of basal belt in most axial sectors, or of high mountain in some pre-Pyrenean sectors) and to the way in which a few factors vary along the altitudinal gradient. For instance, the stronger summer drought at the lower altitudes of sectors 5,6 and 8 may be the cause of their floristic composition (lower medio-European, higher Mediterranean flora, etc.), given the large areas covered by low altitudes.

The most general pattern of species richness in the altitudinal gradient found in the sectors, i.e. an asymmetrical humped pattern, has been related to mountain systems with moderately stressing conditions at the lowest altitudes (i.e. the Mediterranean summer drought in most Pyrenean areas), good conditions in the low-medium zone (with a good hydric balance and still quite a long growing season), and higher stress conditions up to the mountain tops (MCCAIN \& GRYTNES, 2010). However, the low species richness at the lowest altitudes in our approach is clearly more related to the small area covered at these altitudes, which leads to low heterogeneity in causal factors (e.g., outcrops or landscape).

At higher levels, HD decreased from montane to subalpine belts. This even occurred in sectors 1,2 and 3, despite the fact that the projected area for the subalpine belt was greater than that of the montane belt. In sectors 7 and 8 (those without high mountain), HD decreased along the montane belt upwards, more probably due to a sharp area reduction than to bioclimatic conditions. However, grasslands tended to increase with altitude, more sharply across the high mountain. This in- crease may be relevant for plant diversity, since these herbaceous habitats host much of the species richness in mountain landscapes (NINOT \& FERRÉ, 2008).

The richer floras at low-medium altitudes are connected to the rich Mediterranean and medioEuropean (and pluriregional) chorotypes, which are widely found at the submontane and montane belts. These distinct chorotypes coexist at similar altitudes favoured by the varying topography, which offers contrasted habitats in densely arranged landscapes. This contrasts with to the poorer high mountain zone, mainly inhabited by less diversified Alpine, Boreo-Alpine and Pyrenean chorotypes (Table 2). Within the submontane and montane belts, richer flora in the eastern sectors (4 and 7) may be an expression of the very species-rich representation of both medio-European and Mediterranean chorotypes in the mild, maritime mountainous area of NE Catalonia (BoLÒs, 1995). This area has been identified as a good refuge and corridor for many floristic elements throughout the Quaternary climate oscillations (Postigo-Mijarra \& al., 2010).

The distribution of endemics provided complementary evidence of the key role of complex mountainous ecosystems in enhancing floristic richness and singularity. In our case study, most Pyrenean endemics were found in all the sectors that include high mountain landscapes. Namely, all sectors except 7 and 8 hosted between half and two-thirds of the Pyrenean endemics found in the entire study area. Thus, the high mountain has been a refuge for ancient secluded taxa (paleoendemics), an arena for rising speciation (neoendemics), and a relatively good space for internal migration and homogenisation of the Pyrenean high mountain flora.

\section{ACKNOWLEDGEMENTS}

We are grateful to José Manuel Blanco for calculating the PET values and for his comments. This study was supported by the Catalan AGAUR agency (through the 2009 SGR 451 funding to the Geobotany and Vegetation Mapping research group) and the Spanish Ministry of Environment (through the project 634 S/2012 of Organismo Autónomo Parques Nacionales). 


\section{REFERENCES}

Agulló, J.C., Alonso, M.A., Juan, A., Villar, J.L. \& Crespo, M.B. -2010 - Apreciaciones sintaxonómicas y nomenclaturales sobre las comunidades rupícolas de la asociación Jasonio glutinosae-Teucrietum thymifolii Lazaroa 31: 155-163.(

Àrea de Cartografia - 1995- Mapa topogràfic d'Andorra 1:50.000 - Min. d'Ord. Terr. Gov. d'Andorra, Andorra.

Batalla, M., Ninyerola, M. \& Esteban, P. -2011 - Atles climàtic digital d'Andorra (on-line) - Inst. d'Est. Andorrans \& Univ.Aut. Barcelona. http://opengis.uab.es/wms/ACDA.

Birks, H.H. - 2008 - The Late-Quaternary history of arctic and alpine plants - Plant Ecol. Div. 1(2): 135-146.

Bolòs, O. de - 1985 - Corologia de la flora dels Països Catalans. Volum introductori - Inst. d'Est. Catalans. Barcelona.

Bolòs, O. de, Vigo, J. - 1984-2001 - Flora dels Països Catalans. 4 vols. - Barcino. Barcelona.

Bolòs, O. de, Vigo, J., Masalles, R.M., Ninot, J.M. 2005 - Flora manual dels Països Catalans. 3a. ed. Pòrtic. Barcelona.

Carreras, J., Carrillo, E., Ferré, A. \& Ninot, J.M. - 2001Mapa digital dels hàbitats d'Andorra 1:25.000 (on-line) - Univ. Barcelona. Inst. Est. Andorrans. http://www. sigma.ad.

Carreras, J. \& Vendrell, P. (coord.) - 2012 - Cartografia dels hàbitats a Catalunya 1:50.000 (on-line) - Dep. Terr. Sost. Gen. Catalunya. http://www20.gencat/portal/site/mediambient/.

Castro Parga, I. \& Moreno Saiz, J.C - 1996 - Strangthening the natural and national park system of Iberia to conserve vascular plants - Bot. J. Linn. Soc. 121: 189-206.

Comes, H.P. \& Kadereit, J.W. -1998 - The effect of Quaternary climatic changes on plant distribution and evolution - Trends Plant Sci. 3: 432-438.

Crawley, M.J. \& Harral, J.E. -2001- Scale dependence in plant biodiversity - Science 291: 864-868.

de Bello, F., Lavorel, S., Lavergne, S., Albert, C.H., Boulangeat, I., Mazel, F. \& Thuiller, W. -2013- Hierarchical effects of environmental filters on the functional structure of plant communities: a case study in the French Alps - Ecography 36: 393-402.

de Cáceres M. -2012 - Ginkgo user's manual. Version 1.4 - http://biodiver.bio.ub.es/veganaweb/resources/manual-ginkgo/manual.pdf

del Barrio, G. - 1990 - El régimen térmico estacional en alta montaña - In: García Ruiz, J.M. (Ed.). Geoecología de las áreas de montaña. Pp. 117-143. Geoforma. Logroño.

Fernández, M.R. \& Molero, J. - 2011 - The cartography of vegetation in the cryoromediterranean belt of Sierra Nevada: a tool for biodiversity conservation - Lazaroa 32: 101-115.

Font, X. - 2013 - Mòdul Flora i Vegetació. Banc de Dades de Biodiversitat de Catalunya - Gen. Catalunya. Univ. Barcelona. http://biodiver.bio.ub.es/biocat/homepage.html.
Frich, P., Alexander, L.V., Della-Marta, P., Gleason, B., Haylock, M., Klein Tank, A.M.G., Peterson, T. 2002- Observed coherent changes in climatic extremes during the second half of the twentieth century - Clim. Res. 19: 193-212.

Gavilán, R.G., Vilches de la Serna, B. \& Fernández-González, F. -2011 - Syntaxonomical review of Cytisetea scopario-striati communities in central Spain - Lazaroa 32: 29-72.

Grau, O., Ninot, J.M., Font, X., Ferré, A., Grytnes, J.-G. 2011 - Trends in altitudinal distribution of plant diversity in the Catalan Pyrenees - In: Actes del IX Col-loqui Internacional de Botànica Pirenaico-cantàbrica a Ordino, Andorra. Pp. 171-180. Monografies del CENMA (Centre d'Estudis de la Neu i de la Muntanya), Andorra.

Grau, O., Ninot, J.M., Ferré, A., Font, X., Grytnes, J.A. 2012- Altitudinal species richness patterns of vascular plants in the south-eastern Pyrenees and nearby mountains of Catalonia - Plant Ecol. Div. 5(1): 115-126.

Grytnes JA, Vetaas OR. - 2002 - Species richness and altitude, a comparison between simulation models and interpolated plant species richness along the Himalayan altitudinal gradient, Nepal - Am. Nat. 159: 294-304.

ICC (Institut Cartogràfic de Catalunya) - 1989- Mapa geològic de Catalunya $1: 250.000$ - Gen. Catalunya. Barcelona.

ICC (Institut Cartogràfic de Catalunya) - 1992 - Mapa topogràfic de Catalunya $1: 50.000$, versió 1 . Generalitat de Catalunya, Barcelona.

Lobo, J.M., Castro, I. \& Moreno, J.C. - 2001 - Spatial and environmental determinants of vascular plant species richness distribution in the Iberian Peninsula and Balearic Islands - Biol. J. Linn. Soc. 73: 233-253.

Lomolino, M.V. - 2000 - Ecology's most general, yet protean pattern: the species-area relationship $-\mathrm{J}$. Biogeogr. 27: 17-26.

López, S. \& Font, X. - 2006- Propuesta de sectorialización fitogeográfica de la vertiente meridional de los Pirineos - Bull. Soc. Hist. Nat. Toulouse 141(2): 15-19.

López-Sáez, J.A., Sánchez-Mata, D., Alba-Sánchez, F., Abel-Schaad, D., Gavilán, R.G. \& Pérez-Díaz, S. 2013 - Discrimination of Scots pine forests in the Iberian Central System (Pinus sylvestris var. iberica Svoboda, Pinaceae) by means of pollen analysis. Phytosociological considerations - Lazaroa 34 in press.

Mark, A.F. \& Dichinson, K.J.M. -2001 - Alpine vegetation, plant distribution, life forms, and environments in a perhumid New Zealand region: Oceanic and Tropical high mountain affinities - Arc. Antarct. Alp. Res. 32(3): 240-254.

McCain, M. \& Grytnes, J.A. -2010 - Elevational gradients in species richenss - In: Encyclopedia of Life Sciences (ELS). John Wiley \& Sons, Chichester.

Montserrat, G. \& Montserrat, J. — 1990 - Rareza y vulgaridad en la flora de áreas de montaña: el ejemplo de la 
transición climática atlántico-mediterránea en el Pirineo - In: García Ruíz, J.M. (Ed.). Geoecología de las áreas de montaña. Pp. 145-193. Geoforma, Logroño.

Mucina, L. -2010 - Floristic-phytosociological approach, potential natural vegetation, and survival of prejudice Lazaroa 31: 173-182.

Ninot, J.M. - 1998 - Mapa de vegetació de Catalunya 1:50.000. Esterri d'Àneu, 181 (33-9) (Memòria). Inst. Cart. Catalunya. Inst. d'Est. Catalans, Barcelona

Ninot, J.M., Batriu, E., Mercadé, A., Pérez-Haase, A., Carrillo, E., Marc, S. \& Salvat, A. - 2010 - Flora vascular de les Planes de Son i la mata de València - In: Germain, J. (Ed.). Els sistemes naturals de les Planes de Son i la mata de València. Pp. 255-325. Inst. Cat. d'Hist. Nat. Barcelona.

Ninot, J.M., Carrillo, E., Font, X., Carreras, J., Ferré, A., Masalles, R.M., Soriano, I., \& Vigo, J. -2007- Altitude zonation in the Pyrenees. A geobotanic interpretation - Phytocoenologia 37: 371-398.

Ninot, J.M. \& Ferré, A. - 2008 - Plant diversity across five vegetation belts in the Pyrenees (Catalonia, Spain) Collect. Bot. (Barcelona) 27: 65-74.

Ninot, J.M., Rota, C., Carrillo, E. \& Sáez, L. (in review). The endemic vascular flora of the Pyrenees: biological traits, distribution and ecology of exclusively Pyrenean plants - Candollea.

Ninyerola, M., Pons, X. \& Roure, J. -2004- Atles climàtic digital de Catalunya (on-line) - Univ. Aut. Barcelona. http://www.opengis.uab.cat/acdc/index.htm.

Pérez, N. \& Font, X. - 2012- Predicting vascular plant richness patterns in Catalonia (NE Spain) using species distribution models - Appl. Veg. Sci. 15: 390-400.

Pérez-Díaz, S., López-Sáez, J.A., Ruiz-Alonso, M., Zapata, L., \& Abel-Schaad, D. -2013- Holocene history of
Taxus baccata in the Basque Mountains (Northern Iberian Peninsula) - Lazaroa 34 in press.

Postigo-Mijarra, J.M., Morla, C., Barrón, E., Morales-Molino, C. \& García, S. - 2010 - Patterns of extinction and persistence of Arctotertiary flora in Iberia during the Quaternary - Rev. Paleobot Palynol. 162: 416426.

Rivas Martínez, S. - 2008- Worldwide bioclimatic classification system (on-line) - Univ. Complutense. Phytosoc. Res. Center. http://www.globalbioclimatics.org.

Rivas Martínez, S., Báscones, J.C., Díaz, T.E., Fernández-González, F. \& Loidi, J. - 1991 - Vegetación del Pirineo occidental y Navarra - Itinera Geobot. 5: 5456.

Rodríguez Guitián, M.A. - 2010 - Temperate riverside forests without alder trees in the north-west of the Iberian Peninsula: ecology, phytosociological profile and interest for preservation policies - Lazaroa 31: 9-37.

Rodríguez-Rojo, M.P., Crespo, G., Madrigal, J. \& Fernández-González, F. -2012-Contribution to the knowledge of some rare plant communities from the southwestern Iberian System - Lazaroa 33: 27-42.

Sarika, M. - 2012 - Notes on the flora and vegetation of some coastal ecosystems of Sterea Ellas and eastern conti nental Greece (Greece) - Lazaroa 33: 65-99.

Thompson, J.D. - 2005 - Plant Evolution in the Mediterranean - Oxford Univ. Press, Oxford.

Thorthwaite, C.W. - 1948- An approach toward a rational classification of climate - Geogr. Rev. 38: 55-94.

Villar, L., Sesé, J.A. \& Ferrández, J.V. -1997-2001 - Atlas de la flora del Pirineo aragonés. 2 vols. Instituto de Estudios Altoaragoneses - Cons. Protec. Nat. Aragón, Zaragoza.

Received: 1 October 2013

Accepted: 28 October 2013 